\title{
A Green Revolution? A Tentative Assessment of the European Green Deal ${ }^{12}$
}

\section{Siddi}

Marco Siddi - PhD, Senior Research Fellow at Finnish Institute of International Affairs; 23B, Arkadiankatu, 00101 Helsinki, Finland; Marco.Siddi@fiia.fi

\begin{abstract}
In this article the main aspects of the European Green Deal proposed by the European Commission in December 2019 are analyzed, putting the Green Deal into the broader context of European Union (EU) climate governance in order to assess whether and how it advances the EU's climate agenda. Four broad and interrelated categories to evaluate the Green Deal are proposed. Its performance depends on whether it is and will remain a policy priority, despite the COVID-19 emergency and the ensuing economic crisis. Second, successful implementation depends on adequate financial endowment, including the shift of public funding from hydrocarbons to renewables and energy efficiency in post-pandemic economic programmes. The legal competence of EU institutions to coordinate and enforce the implementation of the Green Deal is also essential, as highlighted by ongoing discussions concerning governance to achieve zero net emissions by 2050 . Furthermore, international cooperation with third partners on issues such as border carbon adjustment, technology transfers, and green industry will influence both the implementation of the Green Deal in the EU and the contribution of other major emitters to the climate agenda. The impact of the European Green Deal on EU-Russia relations is also investigated. In this respect, it is argued that the Green Deal poses a serious challenge to the traditional pattern of EU-Russia energy trade, which has been dominated by fossil fuels. However, the Green Deal also offers new avenues for cooperation and for a more sustainable EU-Russia energy relationship.
\end{abstract}

Keywords: European Green Deal; European Union; energy transition; EU-Russia relations; COVID-19; energy policy; climate policy

\footnotetext{
${ }^{1}$ The article was submitted 4 March 2021.

2 An earlier version of this paper was published as Siddi, M. (2020) The European Green Deal: Assessing its current state and future implementation. FIIA Working Paper 114, May 2020
} 
For citation: Siddi M. A Green Revolution? A Tentative Assessment of the European Green Deal. International Organisations Research Journal, vol.16, no 3, pp. 85-107 DOI: https: //doi.org./10.17323/1996-7845-2021-03-04. 


\section{Introduction $^{3}$}

The European Union (EU) has long pursued policies to tackle climate change. It adopted a climate change strategy as early as 1992 and endorsed the goal of limiting global warming to $2^{\circ}$ Celsius above pre-industrial levels in 1996. In the early 2000s, the EU strengthened its credentials as an international leader in addressing climate change when it secured enough followers for the Kyoto Protocol to enter into force despite the withdrawal of the United States [Parker et al., 2017]. Russia's ratification of the Protocol in 2004 was essential in this regard, as the treaty required that a majority of countries approve it and that the signatory states account for $55 \%$ of the world's emissions [Deutsche Welle, 2004].

Ambitious domestic policies backed up the EU's global role. In 2005, the EU launched an emissions trading scheme (ETS) - the world's most important greenhouse gas emissions trading scheme and flagship of the EU's climate policy [Kulovesi, 2017; Lindberg, 2019]. Two years later, it adopted a comprehensive climate legislative package that included the 20-20-20 targets (see discussion of the 2020 Climate and Energy Policy Framework below). At the 2009 UN Climate Change Conference in Copenhagen, the international community failed to secure a global agreement on limiting greenhouse gas (GHG) emissions. Nonetheless, the EU continued to pursue its domestic climate targets and drafted new ones for 2030 [Szulecki, 2016]. The Paris climate agreement of December 2015 was a success for EU diplomacy and encouraged the Union to revise its emission reduction, renewable energy, and energy efficiency goals upward [Oberthür, 2019].

After 2016, the rise to power of leaders hostile to climate action in several major emitters, from Donald Trump in the U.S. to Jair Bolsonaro in Brazil, has challenged EU and global climate action [Vihma, 2019]. In the face of mounting evidence of the climate crisis, the EU has continued to consider climate policy a priority. The European Commission presided over by Ursula von der Leyen, which started its mandate in December 2019, made energy transition one of its main goals and announced that it would pursue a "European Green Deal"henceforth, the Green Deal [EC, 2019a]. The Green Deal can be conceptualized as a road map of key policies for the EU's climate agenda, based on which the Commission has started and will continue to develop legislative proposals and strategies from 2020 onward.

\footnotetext{
${ }^{3}$ See M. Siddi [2020b] for an earlier version of this article.
} 
This article analyzes the main aspects of the proposed Green Deal. First, it puts the Green Deal into the broader context of EU climate governance. In a second step, it presents four broad and interrelated categories to evaluate the performance of the Green Deal: policy priority, financial endowment, legal competence of EU institutions, and international cooperation. These categories have been derived from the main policy issues that emerged from an analysis of relevant official documents (including the Green Deal Communication and the draft European Climate Law) and policy debates thus far. They address the topic through a comprehensive, interdisciplinary approach including political, economic and legal perspectives.

It is argued that the implementation of the Green Deal depends on whether it is and will remain a policy priority in both the short and the long run, an issue which has been aggravated by the COVID-19 emergency and the ensuing economic crisis. Second, successful implementation depends on adequate financial endowment, including the shift of public fund allocation from hydrocarbons to renewables and energy efficiency. The prioritization of the climate agenda in the EU's financial programmes to restart the European economy after the COVID-19 emergency will be an essential factor. The legal competence of EU institutions to frame, coordinate and enforce measures for the implementation of the Green Deal is also of paramount importance, as highlighted by the intra-EU debates concerning the European Climate Law and governance to achieve zero net emissions by 2050. Furthermore, international cooperation with third countries will shape both the implementation of the climate agenda within the EU and the contribution of other major emitters to climate action. In this regard, it is argued in this article that the Green Deal poses a challenge to long-standing trade relationships between the EU and hydrocarbon providers, such as Russia. However, it also offers new avenues for cooperation and for a more sustainable EU-Russia energy relationship focusing on renewable energy and hydrogen technologies.

\section{EU Climate and Energy Governance and the Green Deal}

\section{The 2020 and 2030 Climate and Energy Policy Frameworks}

EU climate and energy governance is structured around three main headline targets concerning GHG emission reduction from 1990 levels, the share of renewable energy in final energy consumption, and an improvement in energy efficiency. For the year 2020, the EU-level goal for each of the three headline targets was $20 \%$. The GHG reduction and renewable energy targets were binding on members, whereas the energy efficiency target was indicative only. 
The EU's 2020 Climate and Energy Policy Framework, adopted in 2007, was implemented through three directives (on the EU's ETS, on renewable energy, and on energy efficiency) and an effort-sharing decision on reduction targets for members' GHG emissions outside the ETS [Oberthür, 2019, p. 18]. Broadly speaking, the ETS aims to cut GHG emissions in power and heat generation, the energy-intensive industry, and the aviation sector [EC, n.d.a]. The effortsharing decision concerns a GHG reduction in most sectors not covered by the ETS, notably transport (excluding aviation), buildings, agriculture and waste [EC, n.d.b].

The 2030 Framework builds on and further develops the 2020 targets. The GHG emission reduction target was initially raised to at least $40 \%$ compared to 1990 levels. This target is implemented through the revised ETS directive (Directive 2018/410) and an effortsharing regulation (Regulation 2018/842) covering non-ETS sectors. The target for renewable energy was increased to at least 32\% (Directive 2018/2001) and that for energy efficiency to at least 32.5\% (Directive 2018/2002). The target for renewables is binding at Union level but, contrary to the 2020 Framework, binding targets for each member are no longer specified. The energy efficiency target remains indicative.

Furthermore, a new directive integrates GHG emissions and removals from land use, land use change, and forestry (LULUCF, Regulation 2018/841) in the 2030 Framework. Based on this regulation, each member will have to ensure that LULUCF emissions do not exceed removals by the sector. Finally, the new Governance Regulation (Regulation 2018/1999) establishes a framework for planning, reporting and review. In particular, it requires each member to submit an integrated national energy and climate plan every 10 years (starting in 2019, with an update every five years), including national contributions to the EU-wide renewable energy and energy efficiency targets and related policies. Biennially, members have to submit progress reports on the implementation of national energy and climate plans and policies for GHG emission reduction. They also have to submit and regularly update long-term strategies for climate and energy covering at least the next 30 years. The European Commission is mandated with the task of assessing draft plans, monitoring progress in implementation, and taking remedial action - mostly in the form of recommendations to members (for more detailed analysis, see S. Oberthür [2019] and M. Ringel and M. Knodt [2018]).

According to the European Environment Agency's 2020 report on trends and projections in Europe, the EU was on track to meet its 2020 GHG emission reduction target. However, it will not achieve the 2030 target based on existing national policies and measures 
[EEA, 2020, pp. 6-9]. The EU was also on track to meet the 2020 renewable target, but it will miss the 2030 goal unless it raises the yearly increase of renewables in final energy consumption from the current $0.7 \%$ (recorded between 2005 and 2017) to at least $1.1 \%$. Furthermore, the EU failed to meet its 2020 energy efficiency target and will also fail to meet the 2030 target, unless annual reductions in energy consumption reach, over the next decade, more than double the average rate of reductions achieved between 2005 and 2017. This highlights that new and ambitious policies are necessary to pursue the climate agenda.

\section{The European Green Deal}

From the beginning of its mandate in December 2019, the new European Commission headed by President Ursula von der Leyen declared climate policy a top priority. At a rhetorical level, to an extent, this differentiates it from the previous Commission, which put stronger emphasis on the security of supply in the wake of the 2014 Ukraine crisis and tensions with Russia [Goldthau, Sitter, 2019; Siddi, 2016, 2019]. Several factors are likely to have contributed to the prioritization of climate policy. The climate crisis has become increasingly evident both in Europe and globally, as highlighted by repeated record high summer and winter temperatures, the melting of polar ice and glaciers, and highly mediatized events such as the catastrophic forest fires in Sweden, Siberia and Australia in 2018-19. In Europe, growing concern about climate change was reflected in stronger electoral support for Green parties in the 2019 European elections, especially in some larger western member states, as well as in the emergence of grassroots movements such as "Fridays for Future" or "Youth Strike for Climate" [Deisenrieder et al., 2020; Mudde, 2019]. Moreover, the rise to power of climate change deniers such as Donald Trump in the U.S. and Jair Bolsonaro in Brazil risked fatally undermining global cooperation on tackling climate change, as enshrined in the Paris climate agreement [Fraune, Knodt, 2018]. All of these factors encouraged the von der Leyen Commission to take the initiative and strengthen the Union's profile in global climate action.

The first concrete step was to reprioritize climate policy in both official discourse and policy documents, expanding on the legislation, targets, and policies already set by the Commission in 2016-18 for the 2030 Climate and Energy Framework. On 11 December 2019, the Commission presented the Communication on the European Green Deal, with the goal of providing an initial road map of the necessary key policies and measures. The Communication highlighted tackling climate and environmental-related challenges as "this generation's defining task." It described the Green Deal as a response to these challenges as well as "a new 
growth strategy that aims to transform the EU into a fair and prosperous society, with a modern, resource-efficient and competitive economy where there are no net emissions of greenhouse gases in 2050 and where economic growth is decoupled from resource use" [EC, 2019a, p. 2].

The pursuit of a just and inclusive transition, including cooperation with international partners, was presented as a key overarching component of the Green Deal.

Achieving zero net GHG emissions by 2050 is arguably the most central, ambitious and challenging goal set out by the Communication. The document highlighted this target again in paragraph 2.1, declaring that the Commission would propose "the first European 'Climate Law' by March 2020" in order to enshrine the 2050 climate neutrality objective in legislation. Moreover, it proposed increasing the EU's 2030 GHG reduction target to at least $50 \%$ and toward 55\% compared with 1990 levels through a revision of climate-related policy instruments [EC, 2019a, pp. 4-5]. From a political perspective, the 2030 goal is particularly important because it requires incumbent governments to take action in the short term [Morgan, 2020a].

In order to meet the higher costs of the energy transition for regions and member states that are more reliant on coal or heavily polluting fossil fuels, the Green Deal Communication also proposed a Just Transition Mechanism and a Just Transition Fund. This was developed further in mid-January 2020, when the Commission presented a regulation to establish the Just Transition Fund [EC, 2020b]. The proposed financial mechanism should also act as an incentive for members such as Poland, one of the largest prospective recipients and the only member that initially refused to commit to the 2050 zero net emission target.

Furthermore, the Green Deal Communication announced the upcoming introduction of various strategies and operational frameworks, some of which are of intrinsic importance- for instance, the carbon border adjustment mechanism (CBAM), the Sustainable Europe Investment Plan, an EU industrial strategy, a circular economy action plan, a new EU Biodiversity Strategy to 2030 and a "farm to fork" sustainable agriculture strategy. Ambitious, long-standing ideas such as mainstreaming sustainability in all EU policies and turning the European Investment Bank into "Europe's climate bank" were reiterated and reframed as targets with indicative deadlines [EC, 2019a, pp. 5-7, 15-6; Szulecki, 2020].

The European Climate Law 
The Green Deal is designed to have a substantial impact on both medium-term goals, for 2030, and long-term targets for 2050. The European Commission's proposal for a draft climate regulation in early March 2020 substantiated the long-term policy goals outlined in the Green Deal Communication. Article 2.1 of the draft regulation states that "Union-wide emissions and removals of greenhouse gases regulated in Union law shall be balanced at the latest by 2050, thus reducing emissions to net zero by that date" [EC, 2020a]. The first draft of the regulation also empowered the Commission to review the trajectory toward the climate neutrality objective every five years starting in 2023, "at the latest within six months after each global stocktake referred to in Article 14 of the Paris Agreement" (Article 3.1). ${ }^{4}$

Furthermore, the Commission was tasked with assessing the collective progress made by all member states toward the climate neutrality objective and on adaptation to climate change, as well as the consistency and adequacy of both Union and national measures (Articles 5 and 6). If the measures of a member are inconsistent with the climate neutrality and adaptation goals, the Commission may "issue recommendations to that member state," which "shall take due account" of them and explain how it has addressed the recommendations in its first progress report (Article 6.2 and 6.3).

The prerogatives of the Commission to review targets every five years were significant and raised controversy with member states and the European Parliament [Morgan 2020b]. Article 3 of the draft regulation empowered the Commission to review the targets by delegated acts, namely without having to go through full negotiations with the European Parliament and the member states. This modus operandi would have strengthened the Commission's mandate and enabled it to act faster and relate better to the global climate agenda. However, Article 3 was modified in later negotiations between the Commission, the European Parliament and the Council of the EU due to the opposition of the Parliament and the Council to delegate these powers to the Commission. Member states were reluctant to transfer competence over sensitive GHG emission reduction targets. The European Parliament and industry also took a sceptical stance because delegating decision-making to the Commission in this area would weaken their power to push through legislative amendments.

\footnotetext{
${ }^{4}$ Negotiations on the European Climate Law are still taking place at the time of writing (February 2020). They involve the European Commission, the European Parliament and the Council of the EU. Some parts of the initial proposal were modified in subsequent drafts. The most relevant changes for this analysis are discussed below.
} 
With regard to the 2030 Framework, the draft regulation stated that the Commission will review the $40 \%$ GHG emission reduction target by September 2020 and "explore options for a new 2030 target of 50 to 55\% emission reductions compared to 1990" (Article 2.3). This would be followed by an assessment, to be made by June 2021, of how related legislation would have to be amended to achieve the higher target (Article 2.4). In September 2020, the Commission raised the 2030 GHG reduction target to "at least 55\%" compared to 1990 levels [EC, 2020d]. This target became the new nationally determined contribution (NDC) of the EU to the Paris climate agreement, namely the GHG reduction target that the Union will officially present in multilateral fora. Conferences of the Parties (COP) of the United Nations Framework Convention on Climate Change (UNFCCC) are the most important of these fora. The EU hopes that its commitment will serve as a stimulus for third countries to present ambitious climate targets prior to the next COP, which will take place in Glasgow in November 2021.

\section{Assessing the Performance of the Green Deal}

\section{Policy Priority}

Maintaining priority in EU and national policy planning throughout the long period over which it will be implemented is the main overarching challenge for the Green Deal. While the climate crisis is a constant reminder of the urgency of climate action, many variables - at times competing ones - can play a role. The recent past has shown how geopolitical crises can shift the attention of European policymakers toward the security of energy supply. In these circumstances, a narrow understanding of the security of supply leads to the prioritization of more polluting domestically produced fossil fuels (notably coal) over less polluting imports. In April 2014, two months after the beginning of the Ukraine crisis, then Polish prime minister (and soon-to-be European Council president) Donald Tusk argued that "Europe should make full use of the fossil fuels available, including coal and shale gas. In the EU's eastern states, Poland among them, coal is synonymous with energy security" [Tusk, 2014]. Future geopolitical crises or international tensions may lead to the return of such political discourse, which pits allegedly secure, domestic fossil fuels against supposedly insecure or more expensive renewable energy.

Rising geopolitical tensions and the fact that some rare earth materials necessary for producing renewable energy need to be imported from competitors such as China have already fuelled zero-sum and realpolitik narratives concerning the "geopolitics of renewable energy." However, more nuanced analyses indicate that, with the growing role of renewables, energy 
systems and geopolitics are likely to be more decentralized and less conflictual and therefore fundamentally different from the current fossil fuel-centred geopolitics of energy [Overland, 2019, pp. 36-40; Paltsev, 2016] (for a comprehensive literature review, see R. Vakulchuk, I. Overland and D. Cholten [2020]).

At present, the main challenge to the Green Deal in terms of policy priority comes from the health emergency caused by the COVID-19 pandemic and, most acutely, from the associated economic slowdown. Prior to the COVID-19 emergency, the Green Deal was arguably at the top of the European Commission's policy agenda. The draft European Climate Law was presented in the week before the Italian government imposed a comprehensive lockdown on the country, a policy that was followed by most member states within days or a few weeks at most. Inevitably, the Green Deal lost its discursive and policy priority in order to allow for a focus on the unprecedented health emergency. In mid-April, the Commission announced that some of the "less essential" initiatives of the Green Deal would be delayed until 2021 (for instance the new EU Strategy on Adaptation to Climate Change and the new EU Forest Strategy), but the schedule for key priorities (such as the assessment of new emission reduction targets for 2030) would be maintained [Simon, 2020].

The risk is that important aspects of the Green Deal will not regain priority even after the health emergency is over. The post-COVID-19 economic recession may induce policymakers to relieve industry of carbon costs or to promote coal bailout measures that artificially extend the operation of already uneconomic coal. Leaders and prominent officials of the member states that are more reluctant to endorse the climate agenda have attempted to pit the Green Deal against the need to focus on boosting the economy. Czech prime minister Andrej Babis argued for scrapping the Green Deal, while Polish deputy minister for state assets Janusz Kowalski stated that the EU ETS should be discontinued from 2021 onward [Elkerbout et al., 2020, p. 2; Khan, Brundsen, 2020].

However, the relationship between the Green Deal and economic recovery is not necessarily competitive or conflictual. The EU's political and economic response to the crisis has continued to prioritize the energy transition so far. During 2020, the European Commission borrowed 750 million euros on financial markets to launch NextGenerationEU, a financial instrument designed to boost the recovery. Moreover, the EU passed a budget for the years 2021-27 (the so-called Multiannual Financial Framework, or MFF) worth 1.1 trillion euros. EU institutions agreed that $30 \%$ of both NextGenerationEU and the MFF will be devoted to 
climate expenditure [Dupont, Oberthür, von Homeyer, 2020, p. 1102]. For a comparison, this is a much greater financial allocation to climate projects than the one agreed upon by the EU after the 2008 financial crisis. The post-2008 European Economic Recovery Programme allocated only $2 \%$ of its 200 billion euros budget to climate and energy spending [Elkerbaut et al., 2020, pp. 4-5].

\section{Financial Endowment}

The Commission has estimated that achieving the current 2030 climate and energy targets will require 260 billion euros in additional annual investment. The Green Deal Communication states that at least $30 \%$ of the InvestEU Fund-a large EU investment scheme expected to trigger at least 650 billion euros in investments in 2021-27-will contribute to fighting climate change. Moreover, the Communication highlights that the European Investment Bank set itself the target of doubling the share of its financing allocated to climate action from 25 to $50 \%$ by 2025 [EC, 2019a, pp. 15-6].

In January 2020, the Commission announced a European Green Deal Investment Plan aimed at "mobilising at least $€ 1$ trillion of sustainable investments over the next decade." This includes the Just Transition Mechanism, which should provide "targeted support to help mobilise at least $€ 100$ billion over the period 2021-2027" in order to alleviate the socioeconomic impact of the transition in regions that rely heavily on the fossil fuel value chain [EC, 2020c]. Some pundits have criticized these figures, arguing that they are only a fraction of what the EU invested to save the banking sector after the 2008 economic crisis. They also cast doubt on whether the funds announced by the EU are new and will indeed materialize [Storm, 2020; Varoufakis, Adler, 2020]. Critics also fear that the Just Transition Mechanism will channel European taxpayer money to influential local elites in charge of the business related to decarbonization, rather than to miners and other key losers of the process [Gabor, 2020].

According to early assessments, a large part of the promised investments comes from the reshuffling of already existing EU funds and especially from the expected mobilization of national and private funds. For instance, in the Green Deal Communication, the Commission proposed an increase in the allocation of the EU budget to climate and environmental expenditures from 20 to $25 \%$. It then counted $25 \%$ of the budget (around 500 billion euros), rather than just the 5\% increase (around 100 billion euros), as part of the promised, additional one trillion euros until 2030 [Claeys, Tagliapietra, 2020]. The one trillion euros figure is also questionable because it remains unclear as to whether the InvestEU fund will indeed manage 
to mobilize the estimated 279 billion euros-mostly private finance-for Green Dealassociated projects. According to some experts, national co-financing will be limited as long as spending for the Green Deal is subject to the rules of the Stability and Growth Pact [Storm, 2020]. Moreover, the actual EU financial endowment for the Just Transition Fund is 7.5 billion euros, while the rest should come from additional funds and private investments [Cameron et al., 2020].

Furthermore, as G. Claeys and S. Tagliapietra noted, the Commission's estimate of 260 billion euros per year of required additional investment is based on the current GHG emission reduction target of $40 \%$ for 2030 . If the target is raised to $50-55 \%$, the necessary investments will be close to 300 billion euros yearly for the rest of the decade [2020]. Hence, the one trillion euros promised by the Commission would only represent a third of the additional investments necessary for the Green Deal. Moreover, it is far from certain whether the sum promised by the Commission will materialize in its entirety. Additional pressure on fund allocation to the Green Deal will come from the aftermath of the COVID-19 emergency and the related economic slowdown. The falling oil price may also discourage investments in renewable energy.

Overall, based on the figures and estimates that the Commission has published and the broader economic context, financial prospects for the Green Deal remain uncertain. A central issue is the reliance of the entire process on large private financiers, many of whom already have substantial investments in the fossil fuel industry and are unlikely to prioritize long-term climate considerations over short-term profit. In order to avoid greenwashing, the Commission is negotiating a "green taxonomy" of assets and activities that are sustainable and that would eventually become eligible to obtain EU subsidies or financial guarantees. However, private lobbying seems to be leading to the inclusion of a broader category of assets, which could provide loopholes for activities that are not sustainable [Gabor 2020; Storm 2020]. Scrutinizing the allocation of funds and their impact on achieving GHG emission reduction targets will therefore be essential in order to assess the performance of the Green Deal.

\section{Competence of EU Institutions}

The degree of legal competence that EU institutions are entrusted with will largely determine the ambition and urgency of Green Deal-related EU policies. With a clear and robust mandate, the Commission is likely to be more ambitious in proposing EU targets and more proactive (and faster) in negotiating with partners in the international arena. However, the Union shares competence with member states in the area of energy and climate policy (see Articles 4 and 
194 of the Treaty on the Functioning of the European Union). Member states are reluctant to relinquish additional sovereignty on decisions that affect the structure of their energy supply and the speed and cost of the energy transition. This does not necessarily mean that members will obstruct or be less ambitious in the implementation of the Green Deal. Based on past experience, some members will probably pursue more ambitious goals than those set at the EU level, while others will be less ambitious - with potential variations within each member state based on the political priorities of successive national governments.

As discussed previously, the EU Council and the European Parliament rejected the proposal to delegate powers to the Commission to set a trajectory toward climate neutrality, which was formulated in the first draft of the European Climate Law. While the European Parliament tends to be ambitious in the advancement of the climate agenda, it is reluctant to transfer competences to the Commission and intends to retain its prerogative to discuss and propose amendments on new climate and energy legislation.

Significantly, on 31 March 2020, an opinion formulated by the European Parliament's legal services stated that delegating power to the Commission to set out the trajectory for achieving climate neutrality by 2050 is not in line with Article 290 of the Treaty on the Functioning of the European Union [European Parliament, 2020]. The legal opinion was formulated at the request of two conservative members of the European Parliament from the Czech Republic and Poland, Alexandr Vondra and Anna Zalewska, who are critical of the 2050 GHG emission reduction target [European Conservatives and Reformists, 2020]. Furthermore, during the redrafting of the European Climate Law in October 2020, member state representatives in the EU Council formally rejected the Commission's proposal to use delegated acts to set a trajectory toward climate neutrality [Agence Europe, 2020].

\section{International Cooperation}

Section 3 of the Green Deal Communication focuses on making the EU a global leader in climate action [EC, 2019a, pp. 20-2]. This is framed in terms of continued EU support for the Paris Agreement and the use of all diplomatic channels in bilateral and multilateral fora (such as the UN, the Group of 7 and the Group of 20) to this end. Particular emphasis is put on supporting the ecological transition in the EU's immediate neighbours, namely the Western Balkans, the Southern Neighbourhood, and the Eastern Partnership countries. The centrality of relations with China and of forging "green alliances" with Africa and the Global South is also stressed. In concrete terms, the proposal to gear EU trade policy to support the ecological 
transition, including commitments to sustainability in EU trade agreements, is one of the most consequential measures. This would include making "respect of the Paris agreement an essential element for all future comprehensive trade agreements” [EC, 2019a, p. 21].

While not explicitly mentioned in the Green Deal Communication, the success of global climate action will largely depend on policy coordination between the three largest GHG emitters - China, the U.S. and the EU [Schreuers, 2016, pp. 219-23]. U.S. president Donald Trump's decision to withdraw from the Paris climate agreement posed the most serious challenge to this coordination. However, following the November 2020 presidential election, newly elected President Joe Biden vowed to rejoin the Paris Agreement. In order to strengthen the international dimension of the Green Deal, the EU can focus on progressively transforming the energy relationship with its main energy partner (and fourth largest GHG emitter), Russia, away from fossil fuels and toward cooperation on renewable energy and energy efficiency [Siddi, 2020a] (see also below). Cooperation with other neighbouring countries can help meet global climate targets. Moreover, it would be cheaper for the EU to achieve drastic emission reductions in countries with less efficient and more energy-intensive industrial sectors than its own [Eyl-Mazzega, 2020].

Coordination with third countries will also be important in the light of measures that will need to be introduced to ensure domestic functioning and to advance the objectives of the Green Deal. Border carbon adjustment is the most important example. Following the Paris climate agreement, global climate governance is based on bottom-up national contributions with varying levels of ambition. Major economies will act according to different timetables and ambition levels. The EU is one of the most ambitious actors in climate policy, with a relatively stringent timetable for emission reductions compared to other major economies. ${ }^{5}$ In order to prevent carbon leakage - the transfer of GHG-intensive production outside the EU, where such emissions may not be taxed-Brussels plans to introduce a CBAM. By taxing foreign producers like domestic producers, the EU wants to ensure that the latter do not incur a competitive disadvantage due to stricter environmental requirements.

A border carbon tax involves several challenges and criticisms. It could disadvantage emerging economies, where industrial processes tend to be less efficient. It could be regarded as "green protectionism" and as incompatible with World Trade Organization (WTO) legislation. It could also be very difficult to implement, as foreign producers' emissions are

\footnotetext{
${ }^{5}$ For a comparative policy assessment, see for instance Climate Action Tracker [CAT, n.d.a].
} 
harder to calculate and verify [Wolff, 2020]. Some analysts have criticized the EU's plan to introduce the CBAM, arguing that it entails too many logistical, legal and political challenges and that it is better to focus on developing a competitive low-carbon industry in Europe [McWilliams, Zachmann, 2020]. Nevertheless, EU policy makers believe that addressing carbon leakage is essential to reconcile the Green Deal with domestic economic interests. The main challenge for the EU in this area will be to devise a mechanism that is compatible with WTO law, does not undermine the interests of the Global South, and incentivizes other major emitters to follow a similar approach, rather than engage in "tariff wars."

Scholars have already presented proposals for border carbon adjustment designs that harness climate benefits while limiting their technical complexities and legal risks [Mehling et al., 2019]. Considering the size of the EU market, the border adjustment mechanism could become an incentive to improve efficiency and reduce GHG emissions in third countries. According to recent analyses, the prospect of an EU carbon border tax has already induced some large foreign companies with a strong presence in the EU market (for instance, the Russian Rusal) to start transitioning to less polluting energy sources [Aris, 2020].

\section{The European Green Deal and Russia}

The European Green Deal will have two types of consequences for Russia. First, as implementation of the energy transition in Europe proceeds, Russia's energy exports to the European market will be affected, especially in the medium and long term. European demand for Russian fossil fuels will decrease. Initially, this will especially affect coal demand, then oil and, after 2030, gas (for an analysis of projections, see I. Makarov, H. Chen and S. Paltsev [2020]). Russia has been increasing exports of fossil fuels to Asia for a decade, and China is now the largest single buyer of Russian oil. However, taken together, European countries are still by far the largest purchasers of Russian oil, coal and gas. Moreover, Asian countries have announced that they will also pursue energy transition. Korea and Japan declared that they aim for climate neutrality by 2050, China by 2060 [Financial Times, 2020]. Consequently, Asia's demand for fossil fuels is expected to decline in the medium and long term.

The second key consequence of the European Green Deal concerns Russian energyintensive exports to Europe, such as metals, chemicals and fertilizers. As explained above, the EU intends to introduce a CBAM, although the details are still to be decided. It could take the form of a tax commensurate to the volume of emissions caused by the production of the 
imported goods. With the tax, the EU aims to both prevent the transfer of carbon-intensive production to countries with weaker environmental standards and induce other countries to adopt similar standards. The tax could significantly affect the price of Russia's metallurgical and chemical products on the European market.

The EU's plan to introduce a carbon border tax has been met with criticism in Russia and in other trade partners of the EU. Many partners see the tax as "green protectionism," that is, as a way of abusing environmental arguments to protect domestic industry. Some Russian actors mentioned that the issue could be taken to the WTO. However, other countries could also adopt carbon border taxes as part of their climate policies, which could therefore become a common practice. If this happens, Russia could introduce its own domestic carbon pricing mechanism. As argued by the Russian presidential advisor on climate issues, Ruslan Edelgeriyev, this would ensure that carbon fees are collected in Russia rather than abroad (cited in I. Makarov [2021]).

From Russia's perspective, investing in the energy transition can bring several significant advantages. If it develops a specialization in clean energy technologies, Russia will be able to compete for a share of a growing and promising global market. Hydrogen production - especially from renewables - can open the way for a more sustainable type of energy partnership with European countries, relying on the already existing network of gas pipelines for transportation. As J. Henderson and T. Mitrova [2019] have argued, Russia has enormous potential to produce hydrogen and export it on a global scale.

Thanks to its natural endowments, Russia could become a "green energy power": the country has huge potential for developing renewable energy. Moreover, renewable energyfor instance wind power - can be developed and used locally to satisfy the demand of relatively small urban centres in the vast Russian North and East. This is more cost-efficient than linking them to a centralized power grid over hundreds of kilometres [Ibid.].

While the energy transition requires a rethinking and progressive transformation of the EU-Russia energy partnership, green energy cooperation could be based on already existing corporate and trade networks. Some European companies have already invested in the renewables sector in Russia. The Italian ENEL provides an apt example. Its Russian branch EnelRussia has built wind farms in the Murmansk, Stavropol and Azov regions [Enel Russia, 2019]. Other European companies that have long been active in the Russian fossil fuel sector 
are also greening their portfolios and could use their operational expertise in Russia to make new, greener investments.

Furthermore, commitment to the energy transition also has wider, political significance. As discussed above, climate change is a top concern in the EU, especially for the younger generation [EC, 2019b]. Awareness of the disastrous consequences of climate change is growing in Russia, too [Russian Analytical Digest, 2020]; for a discussion, see J. Lassila and M. Siddi [2021]. Hence, there would most probably be strong public support for common initiatives that address climate change. Shared commitment and joint EU-Russia efforts to tackle climate change and foster the energy transition could be a significant step toward rebuilding a relationship that has been marred by numerous crises in recent years.

\section{Conclusion}

The European Commission has pursued climate action in a challenging international setting, amidst growing geopolitical tensions, the rise to power of climate change deniers in major emitters, a pandemic, and the ensuing economic slowdown. Opposition to ambitious climate action also exists inside the ranks of the EU, particularly among Eastern and Central European countries that are concerned about the costs of the energy transition. In this context, the implementation of the Green Deal will face numerous obstacles. Its outcome will depend on several essential prerequisites. Careful scrutiny of four broad and interrelated factors will be necessary. Policy priority will remain essential and will be reflected in the funding assigned to green projects in the post-COVID-19 recovery programmes. At the time of writing, the EU's post-pandemic recovery plans reiterate the importance of the energy transition.

The European Commission also needs to ensure that the additional allocation of funds for the Green Deal is indeed supplementary to the pre-existing budget, rather than a reshuffling of commitments already made. Reliance on private investments should be regulated carefully, as it involves the risk of making the Green Deal subject to corporate interests that are heavily invested in the fossil fuel industry. Another risk is that EU public investments in the green sector do not generate the expected multiplier effect from the private sector. Additionally, if EU funds do not reach the main losers from the energy transitions (for instance, workers of the regions more heavily dependent on the fossil fuel industry), poverty and discontent could become widespread. 
A strong legal mandate that simultaneously preserves democratic scrutiny will encourage the European Commission to pursue bolder targets, as well as more proactive strategies in negotiations with other major emitters. Even while climate policy and science are the subject of heavy political contestation in the U.S. (the world's second largest emitter) and China takes an ambiguous stance on phasing out coal [CAT, n.d.b], the EU can continue to pursue the energy transition in cooperation with other major global players and polluters, such as Russia. Russia's vast resources for renewable energy and hydrogen production provide an important opportunity for sectoral cooperation in decades to come. Furthermore, the EU can also make a fundamental contribution to climate action through technology and financial transfers to countries of the Global South, where GHG emissions can be reduced substantially by overhauling inefficient production processes.

\section{References}

Agence Europe (2020) "Climate Law," Partial Political Agreement of European Environment Ministers Excluding Question of 2030 Objective. Europe Daily Bulletin No 12588. Available at: https://agenceurope.eu/en/bulletin/article/12588/1 (accessed 6 August 2021).

Aris B. (2020) Europe's Plan to Introduce a Carbon Import Tax Is Forcing Russia to Go Green. bne IntelliNews, 8 March. Available at: https://www.intellinews.com/europe-s-plan-tointroduce-a-carbon-import-tax-is-forcing-russia-to-go-green-178003/ (accessed 6 August 2021).

Cameron A., Claeys G., Midões C., Tagliapietra S. (2020) How Good Is the European Commission's Just Transition Fund Proposal? Policy Contribution Issue No 4, Bruegel. Available at: https://www.bruegel.org/wp-content/uploads/2020/02/PC-04_2020-V2.pdf (accessed 6 August 2021).

Claeys G., Tagliapietra S. (2020) A Trillion Reasons to Scrutinise the Green Deal Investment Plan. Blog Post, 15 January, Bruegel. Available at: https://www.bruegel.org/2020/01/a-trillionreasons-to-scrutinise-the-green-deal-investment-plan/ (accessed 6 August 2021).

Climate Action Tracker (CAT) (n.d.a) Available at: https://climateactiontracker.org/countries/china/ (accessed 20 September 2021).

Climate Action Tracker (CAT) (n.d.b) China. Available at: https://climateactiontracker.org (accessed 20 September 2021).

Deisenrieder V., Kubisch S., Keller L., Stötter J. (2020) Bridging the Action Gap by Democratizing Climate Change Education-The Case of k.i.d.Z.21 in the Context of Fridays for Future. Sustainability, vol. 12, issue 5, pp. 1-19. Available at: https://doi.org/10.3390/su12051748. 
Deutsche Welle (2004) Russia Ratifies Kyoto Protocol. 23 October. Available at: https://www.dw.com/en/russia-ratifies-kyoto-protocol/a-1369643 (accessed 6 August 2021).

Dupont C., Oberthür S., von Homeyer I. (2020) The Covid-19 Crisis: A Critical Juncture for EU Climate Policy Development? Journal of European Integration, vol. 42, issue 8, pp. 1095110. Available at: https://doi.org/10.1080/07036337.2020.1853117.

Elkerbout M., Egenhofer C., Núñez Ferrer J., Catuti M., Kustova I., Rizos V. (2020) The European Green Deal After Corona: Implications for EU Climate Policy. CEPS Policy Insight 2020/6, Centre for European Policy Studies. Available at: https://www.ceps.eu/wpcontent/uploads/2020/03/PI2020-06_European-Green-Deal-after-Corona.pdf (accessed 6 August 2021).

Enel Russia (2019) Construction Begins at 201 MW Kolskaya Wind Farm, Largest Renewable Project Beyond the Arctic Circle. Press Release, 19 September. Available at: https://www.enelrussia.ru/en/media/press/d201909-enel-russia-construction-begins-at-201mw-kolskaya-wind-farm-largest-renewable-project-beyond-the-arctic-circle.html (accessed 6 August 2021).

European Commission (EC) (2019a) The European Green Deal. COM(2019) 640 final. Brussels, 11 December. Available at: https://ec.europa.eu/info/sites/info/files/european-greendeal-communication_en.pdf (accessed 6 August 2021).

European Commission (EC) (2019b) Report: Climate Change. Special Eurobarometer 490. Available at: https://ec.europa.eu/clima/sites/clima/files/support/docs/report_2019_en.pdf (accessed 6 August 2021).

European Commission (EC) (2020a) Proposal for a Regulation of the European Parliament and of the Council Establishing the Framework for Achieving Climate Neutrality and Amending Regulation (EU) 2018/1999 (European Climate Law). COM(2020) 80 final. Brussels, 4 March. Available at: https://eur-lex.europa.eu/legal-content/EN/TXT/?uri=CELEX:52020PC0080 (accessed 6 August 2021).

European Commission (EC) (2020b) Proposal for a Regulation of the European Parliament and of the Council Establishing the Just Transition Fund. COM(2020) 22 final. Brussels, 14 January. Available at: https://eur-lex.europa.eu/legalcontent/EN/TXT/?uri=CELEX\%3A52020PC0022 (accessed 6 August 2021).

European Commission (EC) (2020c) Financing the Green Transition: The European Green Deal Investment Plan and Just Transition Mechanism. Press Release, 14 January. Available at: https://ec.europa.eu/commission/presscorner/detail/en/ip_20_17 (accessed 6 August 2021).

European Commission (EC) (2020d) Stepping up Europe's 2030 Climate Ambition. Investing in a Climate-Neutral Future for the Benefit of Our People. COM(2020) 562 final. Brussels, 17 September. Available at: https://eur-lex.europa.eu/legalcontent/EN/TXT/?uri=COM:2020:562:FIN (accessed 6 August 2021).

European Commission (EC) (n.d.a) EU Emissions Trading System (EU ETS). Available at: https://ec.europa.eu/clima/policies/ets_en (accessed 19 September 2021). 
European Commission (EC) (n.d.b) Effort Sharing: Member States' Emission Targets. Available at: https://ec.europa.eu/clima/policies/effort_en (accessed 19 September 2021).

European Conservatives and Reformists (2020) Legal Opinion: Green Deal Delegated Acts Are Incompatible With EU Treaties. 2 April. Available at: https://ecrgroup.eu/article/legal_opinion_green_deal_delegated_acts_are_incompatible_with_ eu_treaties (accessed 6 August 2021).

European Environment Agency (EEA) (2020) Trends and Projections in Europe 2020: Tracking Progress Towards Europe's Climate and Energy Targets. EEA Report 13/2020. Available at: https://www.eea.europa.eu//publications/trends-and-projections-in-europe-2020 (accessed 6 August 2021).

European Parliament (2020) Non-Paper on the Choice of Delegated Acts to Set Out the Trajectory for Achieving Climate Neutrality in the Proposal for a European Climate Law [2020/0036(COD)], 31 March. Available at: https://www.politico.eu/wpcontent/uploads/2020/04/Climate-law-paper-NON_PAPER.pdf (accessed 6 August 2021).

Eyl-Mazzega M.-A. (2020) EU Green Deal: Meeting Targets by Lowering Non-EU Neighbour Emissions Too. Energy Post, 13 March. Available at: https://energypost.eu/eu-green-dealmeeting-targets-by-lowering-non-eu-neighbour-emissions-too/ (accessed 6 August 2021).

Financial Times (2020) South Korea Follows Japan and China in Carbon Neutral Pledge. 27 October. Available at: https://www.ft.com/content/185e5043-fd72-4fef-a05c-f2a5001c7f4b (accessed 6 August 2021).

Fraune C., Knodt M. (2018) Sustainable Energy Transformations in an Age of Populism, PostTruth Politics, and Local Resistance. Energy Research \& Social Science, vol. 43, pp. 1-7. Available at: https://doi.org/10.1016/j.erss.2018.05.029.

Gabor D. (2020) The European Green Deal Will Bypass the Poor and Go Straight to the Rich. The Guardian, 19 February. Available at:

https://www.theguardian.com/commentisfree/2020/feb/19/european-green-deal-polish-miners (accessed 6 August 2021).

Goldthau A., Sitter N. (2019) Regulatory or Market Power Europe? EU Leadership Models for International Energy Governance. New Political Economy of Energy in Europe (J. M. Godzimirski (ed)). Cham: Palgrave. Available at: https://doi.org/10.1007/978-3-319-93360$3 \_2$.

Henderson J., Mitrova T. (2020) Implications of the Global Energy Transition on Russia. The Geopolitics of the Global Energy Transition (M. Hafner, S. Tagliapietra (eds)). Cham:

Palgrave. Available at: https://doi.org/10.1007/978-3-030-39066-2_5.

Khan M., Brunsden J. (2020) Dumping Europe's Green Ideals. Financial Times, 3 April. Available at: https://www.ft.com/content/2c44c927-f007-4fbd-8b20-4d467c45a0c2 (accessed 6 August 2021).

Kulovesi K. (2017) EU Emissions Trading Scheme: Preventing Carbon Leakage Before and After the Paris Agreement. Research Handbook on EU Energy Law and Policy (R. Leal-Arcas (ed)). Cheltenham: Edward Elgar. 
Lassila J., Siddi M. (2021) Russia Meets Climate Change: The Domestic Politicization of Environmental Issues and External Pressure to Decarbonize. FIIA Briefing Paper 303, Finnish Institute of International Affairs. Available at: https://www.fiia.fi/wpcontent/uploads/2021/03/bp303_russia-meets-climate-change.pdf (accessed 6 August 2021).

Lindberg M. B. (2019) The EU Emissions Trading System and Renewable Energy Policies: Friends or Foes in the European Policy Mix? Politics and Governance, vol. 7, no 1, pp. 10523. Available at: https://doi.org/10.17645/pag.v7i1.1800.

Makarov I. (2021) The External Dimension of the European Green Deal: Russia's Perspective. MDPD Paper No 2, Multinational Development Policy Dialogue Brussels. Available at: https://www.kas.de/en/web/mned-bruessel/european-green-deal/detail/-/content/the-externaldimension-of-the-european-green-deal-russia-s-perspective (accessed 6 August 2021).

Makarov I., Chen H., Paltsev S. (2020) Impacts of Climate Change Policies Worldwide on the Russian Economy. Climate Policy, vol. 20, issue 10, pp. 1242-56. Available at: https://doi.org/10.1080/14693062.2020.1781047.

McWilliams B., Zachmann G. (2020) A European Carbon Border Tax: Much Pain, Little Gain. Policy Contribution 05/2020, Bruegel. Available at: https://www.bruegel.org/2020/03/aeuropean-carbon-border-tax-much-pain-little-gain/ (accessed 1 October 2021).

Mehling M., van Asselt H., Das K., Droege S., Verkuijl C. (2019) Designing Border Carbon Adjustments for Enhanced Climate Action. American Journal of International Law, vol. 113, issue 3, pp. 433-81. Available at: https://doi.org/10.1017/ajil.2019.22.

Morgan S. (2020a) EU's Next Top Climate Model Under Scrutiny. Euractiv, 5 March. Available at: https://www.euractiv.com/section/climate-environment/news/eus-next-topclimate-model-under-scrutiny/ (accessed 6 August 2021).

Morgan S. (2020b) EU's Draft Climate Law Leaves 2030 Target up in the Air. Euractiv, 3 March. Available at: https://www.euractiv.com/section/energy-environment/news/leak-eusdraft-climate-law-leaves-2030-target-up-in-the-air/ (accessed 6 August 2021).

Mudde C. (2019) The 2019 EU Elections: Moving the Center. Journal of Democracy, vol. 30, issue 4, pp. 20-34. Available at: https://doi.org/10.1353/jod.2019.0066.

Oberthür S. (2019) Hard or Soft Governance? The EU's Climate and Energy Policy Framework for 2030. Politics and Governance, vol. 7, no 1, pp. 17-27. Available at: https://doi.org/10.17645/pag.v7i1.1796.

Overland I. (2019) The Geopolitics of Renewable Energy: Debunking Four Emerging Myths. Energy Research \& Social Science, vol. 49, pp. 36-40. Available at: https://doi.org/10.1016/j.erss.2018.10.018.

Paltsev S. (2016) The Complicated Geopolitics of Renewable Energy. Bulletin of the Atomic Scientists, vol. 72, pp. 390-5. Available at: https://doi.org/10.1080/00963402.2016.1240476.

Parker C. F., Karlsson C., Hjerpe M. (2017) Assessing the European Union's Global Climate Change Leadership: From Copenhagen to the Paris Agreement. Journal of European Integration, vol. 39, issue 2, pp. 239-52. Available at: https://doi.org/10.1080/07036337.2016.1275608. 
Ringel M., Knodt M. (2018) The Governance of the European Energy Union: Efficiency, Effectiveness and Acceptance of the Winter Package 2016. Energy Policy, vol. 112, pp. 20920. Available at: https://doi.org/10.1016/j.enpol.2017.09.047.

Russian Analytical Digest (2019) Climate Change and Russia. No 243, 11 December. Available at: https://css.ethz.ch/content/dam/ethz/special-interest/gess/cis/center-forsecurities-studies/pdfs/RAD243.pdf (accessed 6 August 2021).

Siddi M. (2016) The EU's Energy Union: A Sustainable Path to Energy Security? The International Spectator, vol. 51, issue 1, pp. 131-44. Available at: https://doi.org/10.1080/03932729.2016.1090827.

Siddi M. (2019) The EU's Botched Geopolitical Approach to External Energy Policy: The Case of the Southern Gas Corridor. Geopolitics, vol. 24, issue 1, pp. 124-44. Available at: https://doi.org/10.1080/14650045.2017.1416606.

Siddi M. (2020a) EU-Russia Energy Relations. Handbook of Energy Governance in Europe (M. Knodt, J. Kemmerzell (eds)). Springer. Available at: http://dx.doi.org/10.1007/978-3-31973526-9_54-1.

Siddi M. (2020b) The European Green Deal: Assessing Its Current State and Future Implementation. FIIA Working Paper 114, Finnish Institute of International Affairs. Available at: $\quad$ https://www.fiia.fi/wp-content/uploads/2020/05/wp114_european-green-deal.pdf (accessed 6 August 2021).

Simon F. (2020) Full List of Delayed European Green Deal Initiatives. Euractiv, 16 April. Available at: https://www.euractiv.com/section/energy-environment/news/leaked-full-list-ofdelayed-european-green-deal-initiatives/ (accessed 6 August 2021).

Storm S. (2020) The EU's Green Deal: Bismarck's “What Is Possible” versus Thunberg's "What Is Imperative" in the Age of Covid-19. Brave New Europe, 1 April. Available at: https://braveneweurope.com/servaas-storm-the-eus-green-deal-bismarcks-what-is-possibleversus-thunbergs-what-is-imperative-in-the-age-of-covid-19 (accessed 6 August 2021).

Szulecki K. (2020) Europe's Greenest Commission Ever Faces an Unprecedented Challenge as the Clock Ticks. Dahrendorf Forum, 16 January. Available at: https://www.dahrendorfforum.eu/europes-greenest-commission-ever-faces-an-unprecedented-challenge-as-the-clockticks/ (accessed 6 August 2021).

Tusk D. (2014) A United Europe Can End Russia's Energy Stranglehold. Financial Times, 21 April. Available at: https://www.ft.com/content/91508464-c661-11e3-ba0e-00144feabdc0 (accessed 6 August 2021).

Vakulchuk R., Overland I., Cholten D. (2020) Renewable Energy and Geopolitics: A Review. Renewable and Sustainable Energy Reviews, vol. 122, pp. 1-12. Available at: https://doi.org/10.1016/j.rser.2019.109547.

Varoufakis Y., Adler D. (2020) The EU's Green Deal Is a Colossal Exercise in Greenwashing. The Guardian, 7 February. Available at: https://www.theguardian.com/commentisfree/2020/feb/07/eu-green-deal-greenwash-ursulavon-der-leyen-climate (accessed 6 August 2021). 
Vihma A. (2019) What's Next for UN Climate Negotiations? The UNFCCC in the Era of Populism and Multipolar Competition. FIIA Briefing Paper 257, Finnish Institute of International Affairs. Available at: https://www.fiia.fi/wp-

content/uploads/2019/03/bp257_un_climate_negotiation-1.pdf (accessed 6 August 2021).

Wolff G. (2020) Why Border Carbon Adjustment Is Important for Europe's Green Deal. Bruegel, 27 November. Available at: https://www.bruegel.org/2019/11/a-value-added-taxcould-reduce-carbon-leakage/ (accessed 6 August 2021). 